\title{
直格子斜桁橋の固有振動数に関する研究 \\ FREE VIBRATION IN SKEW GIRDER BRIDGES WITH RIGHT GRILLAGE SYSTEM
}

\author{
成 岡 昌夫* -大村 裕** \\ 中川建 治*** - 山口富 夫**** \\ By Masao Naruoka, Hiroshi Ohmura, \\ Kenji Nakagawa and Tomio Yamaguchi
}

要 旨 直格子斜析橋の固有振動数を格子桁理論と 直交異方性平行四辺形板理論とを用いて求め, 実橋およ びアクリライト模型橋について，計算值を実測值と比較 したものである。

\section{まえがき}

著者の一人は, 文献1)の研究, および, その後の研究 によって, 直桁橋の固有振動数については, 「その平面 形が細長く，桁橋をむしろ桁とみなしてさしつかえない ような場合に対しては，桁の固有振動数の公式をそのま ま用いてもよい。平面形が正方形か，もしくは，これに 近い上うな場合には，おのおのの桁が同一モードで振動 する場合，すなわち，桁橋の固有振動数が析の固有振動 数と一致する場合もありえようが，幅員の広い桁橋で は, 桁の固有振動数と全く異なる固有振動数をもつ振動 が現われることがある。この場合に対しては，直交異方 性長方形板理論を用いて，容易に解決できる。」との結 論を得た。

すなわち，桁は曲げ剛性 $E I$ のみによって論じてよい が, 析橋については, 曲げ剛性 $B_{x}, B_{y}$, および, aspect ratio $(b / a)$ より求められる stiffness ratio $\theta=(b / 2 a)$ ・ $\left(B_{x} / B_{y}\right)^{1 / 4}$ ，および, torsional parameter $\kappa=H /\left(B_{x}\right.$. $\left.B_{y}\right)^{1 / 2}$ より論じなければならないことは, 桁の荷重分配 理論ではすでに常識となっている。幅員の広い桁橋にお いて，各桁が同一のモードで振動しない場合の桁橋とし ての固有振動数についても，全く同一の見地から考えな ければならない。

しかるに，直格子 斜析橋においては， 上記の $\kappa, \theta$ の $2 つ$ の項のほかに, 斜角 の影響が入ってくる はずである。この研 究においては, 直格 子斜桁橋 $2 \supset\{-0$

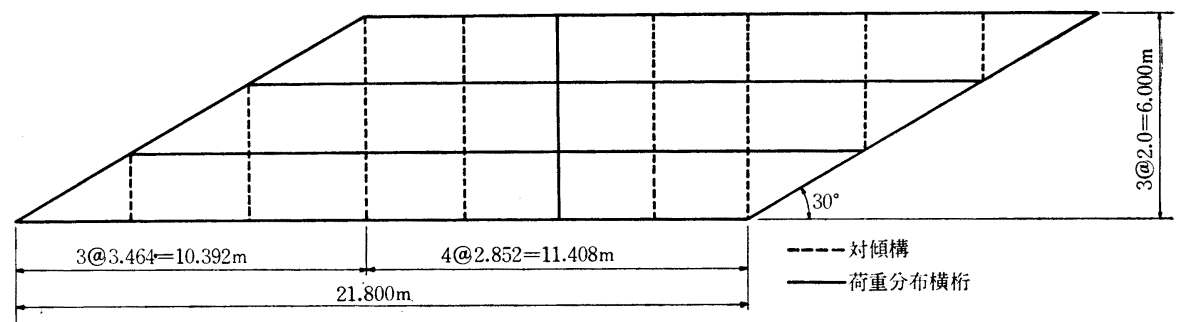

は aspect ratio が小さく(細長い)，一つは大きい（幅 員が広い)\}，および，直格子斜桁橋のアクリライト模型 (上記の幅員の広い斜桁橋の模型)（比較のために直桁橋 の模型もつくった）の固有振動数を実測し，これらを， 格子桁理論, および, 直交異方性平行四辺形板理論によ る計算值と比較し，斜角を無視して桁および直桁橋とみ なした計算値といかに異なるかを調べたものである。

この数值計算に扔いては, NEAC 2203 (名古屋大学), および，IBM 7044 (三菱重工業(株))を用いた。

\section{第 1 編 純信橋の固有振動数に ついての研究}

本橋は, $l=21.8 \mathrm{~m}, b=7.5 \mathrm{~m}, 2$ 等橋の合成，直格子 斜桁橋で, 直交異方性平行四辺形板理論を用いて設計さ れた。設計の詳細，および，静的載荷試験の結果につい ては，文献 2)，3）に述べられている。本橋の骨組図を 図一1に示す。自動車荷重走行時における外桁, および, 内桁の $l / 4$ ごとの断面のひずみのオッシログラムから固 有振動数を求めると, 10 回の走行の平均值として, つ ぎのような值が得られている。

表一1 純信橋の固有振動数 (cycle/sec)

\begin{tabular}{cc|c|c|c}
\hline 断 & 面 & $l / 4$ & $2 l / 4$ & $3 l / 4$ \\
\hline 外 & 杯 & 8.55 & 8.55 & 8.55 \\
内 & 側 & 8.27 & 8.62 & 8.62 \\
\hline
\end{tabular}

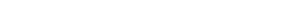

\section{1. 本橋の概要および実測值}

これらの平均をとって, 純信橋の固有振動数の実測值 として $f=8.5 \mathrm{cycle} / \mathrm{sec}$ を得る。測定時の不注意か ら，この固有振動数がいかなるモードに対応するもの か，明らかでない。 
本橋の単位面積あたりの重量 $\left(\mathrm{kg} / \mathrm{m}^{2}\right)$ は, 鋼重 : 116 , 高欄 : 11 , 床板 : 400 , 舗装 : 71 , 地覆 : 25 , ハンチ $: 5$, 合計 $628 \mathrm{~kg} / \mathrm{m}^{2}$ である。

\section{2. 固有振動数の計算ならびに検討（その 1）}

\section{(1) 桁理論による検討}

主桁の断面 2 次モーメントは, 外桁で $1763.500 \mathrm{~cm}^{4}$, 中桁で $1605.200 \mathrm{~cm}^{4}$ で, 平均 $1684.400 \mathrm{~cm}^{4}$ である。 したがって, 単純桁の固有振動数の公式において

$$
f=\frac{\pi}{2 l^{2}} \sqrt{\frac{E I g}{A r}}
$$

において, $E I=2.1 \times 10^{6} \cdot 1.684 \times 10^{6} \mathrm{~kg} \cdot \mathrm{cm}^{2}, g=9.8 \times$ $10^{2} \mathrm{~cm} / \mathrm{sec}^{2}, l=2180 \mathrm{~cm}, A r=628 \times 2=1256 \mathrm{~kg} / \mathrm{m}=$ $12.56 \mathrm{~kg} / \mathrm{cm}$ を代入すると，

$$
f=5.5 \mathrm{cycle} / \mathrm{sec}
$$

となる。

\section{（2）直交異方性長方形板理論による検討}

一方, 斜角を無視し,直格子直析橋として, 直交異方性 長方形板理論を用いて解くことにしょう。 $B_{x}=8026 E_{s}$ (中桁加計算する) $, B_{y}=166 E_{s}, 2 b=600, l=2180$ の直交異方性長方形板が $E I_{R}=1763500 E_{s}$ の縁桁によ って弾性ばり支持されるものとする。この場合, 計算に 必要な数值は，つぎのようである。以下すべて， $n=1$ の場合を考える。

$$
\begin{aligned}
& \alpha=0.3801, \phi=0.4571, \rho=64 \times 10^{-6} \\
& \left(\rho p^{2} / B_{x}\right)(l / \pi)^{4}=0.8813 p^{2} \times 10^{-3}
\end{aligned}
$$

a) 橋軸に対称な振動の場合 torsional parameter $\boldsymbol{n}=0$ と仮定すれば, 文献 1) による試算の結果, 振動 数方程式 $\Delta=0$ の根は,

$$
\begin{aligned}
& p=45, \Delta=-1.52 ; p=40, \Delta=-0.31 ; p=35, \\
& \Delta=0.53 ; p=30, \Delta=0.86
\end{aligned}
$$

から， $p=38.5, f=p / 2 \pi=6.1 \mathrm{cycle} / \mathrm{sec}$ となる。

つぎに， $\kappa=1$ と仮定すれば, $\Delta=0$ の根は，

$$
\begin{aligned}
& p=50, \Delta=-1.55 ; p=45, \Delta=-0.56 ; p=40, \\
& \Delta=0.20 ; p=35, \Delta=0.61
\end{aligned}
$$

から, $p=41.5, f=p / 2 \pi=6.6 \mathrm{cycle} / \mathrm{sec}$ となる。

もし, 荷重分布係数についての Guyon-Massonnet 式 と同じ形の式が，固有振動数についても成立するものと 仮定すれば，純信橋の場合は， $\kappa=0.26^{1}$ であるから，

$$
\begin{aligned}
f_{\kappa} & =f_{0}+\left(f_{1}-f_{0}\right) \sqrt{\kappa}=6.1+(6.6-6.1) \sqrt{0.26} \\
& =6.4 \mathrm{cycle} / \mathrm{sec}
\end{aligned}
$$

となる。

b) 橋軸に逆対称な振動の場合 この場合の振動数 方程式は文献 1) に記載してないので, ここに示そう。 文献 1) と全く同じ符号を用いて，

$\kappa=0$ の場合 : $\left(\rho p^{2} / B_{x}\right) \cdot(l / n \pi)^{4}-1>0$ ならば

$2 \phi \cdot \tanh r b \cdot \tan r b-r^{3}(\tan r b-\tanh r b)=0$

$\kappa=1$ の場合 : $\left\{\left(\rho p^{2} / B_{x}\right) \cdot(l / n \pi)^{4}\right\}^{1 / 2}-1>0$ ならば

$\phi\left(\gamma^{2}+\gamma^{\prime 2}\right) \cdot \tanh r b \cdot \tan r^{\prime} b-r^{2} \gamma^{\prime 2}\left(\gamma \tan r^{\prime} b\right.$

$$
\left.-r^{\prime} \tanh \cdot r b\right)=0
$$

この場合の計算結果は,つぎのようである。

$\kappa=0$ の場合 : $p=40, \Delta=0.38 ; p=45, \Delta=0.15 ; p=$ $50, \Delta=-0.44 ; p=55, \Delta=-1.14$ 加,$\Delta(p=47)=0$ となる。したがって, $f=p / 2 \pi=7.5 \mathrm{cycle} / \mathrm{sec}$

$\kappa=1$ の場合 : $p=40, \Delta=0.26 ; p=45, \Delta=0.20 ; p=$ $50, \Delta=-0.10 ; p=55, \Delta=-0.42$ 加,$\Delta(p=49)=0$ となる。したがって， $f=p / 2 \pi=7.8 \mathrm{cycle} / \mathrm{sec}$ を得る。

橋軸に対称な振動の場合と同様に, $\kappa=0.26$ の場合を 求めると,

$$
\begin{aligned}
f_{\kappa} & =f_{0}+\left(f_{1}-f_{0}\right) \sqrt{\kappa}=7.5+(7.8-7.5) \sqrt{0.26} \\
& =7.7 \mathrm{cycle} / \mathrm{sec}
\end{aligned}
$$

\section{（3）直交異方性平行四辺形板理論による検討}

そもそも，本橋は直交異方性平行四辺形板理論を用い て解析・設計されているので, 固有振動数の計算にあた って,この理論を用いることとする。直格子斜桁橋を直 交異方性平行四辺形板とみなし, skew network でおお う。格子点において, その点の性僙に応じて, 文献 4) の 9 種類の階差方程式をたてる。分布荷重載荷の場合に は, 階差方程式の右辺は, 縁辺上の格子点に対しては $q_{i} \lambda_{y}{ }^{4} / 2 B_{y}$, その他の内点に対しては, $q_{i} \lambda_{y}{ }^{4} / B_{y}$ である。 自由振動の場合には， $q_{i}$ のかわりに， $\rho p^{2} w_{i}$ とすれば よろしい。ここに, $\rho$ は (単位面積あたりの重量)/(重 力加速度), すなわち, 単位面積あたりの質量, $p$ は円 振動数である。

さて, 純信橋の設計にあたっては, 直交異方性平行四 辺形板が外桁で弾性ばり支持されているものとし，21.8 $\times 6.0 \mathrm{~m}$ の平行四辺形板を $8 \times 6$ の skew network でお おったが, 固有振動数の計算においては, 中型計算機 NEAC 2203 による固有值計算の困難さを考えて, $6 \times 6$ の skew network を組むことにした。この場合の平行四 辺形板は, 計算を容易にするために, Guyon-Massonnet 流に, 縁辺自由とし, したがって, $21.8 \times 8.0 \mathrm{~m}$ の平行 四辺形板を考えた。この場合の skew network を図一2 に示す。図一2 における縁辺 (自由辺) 上の格子点に対 する階差方程式の右辺は $\rho p^{2} \lambda_{y}{ }^{4} \cdot w_{i} / 2 B_{y}$, その他の内点 については, $\rho p^{2} \lambda_{y}{ }^{4} \cdot w_{i} / B_{y}$ である。

\section{図一2 固有值計算の対象とした skew network}

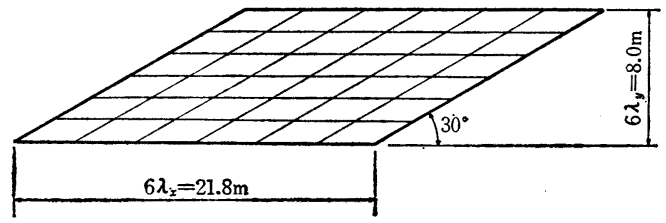

純信橋の固有振動数の計算にあたっては, 計算の便宜 上, 外・中桁の断面 2 次モーメントの平均値, 1684400 $E_{s} \mathrm{~cm}^{4}$ をもって, $B_{x}=8422 E_{s}$ ときめ, $\alpha=\sqrt{B_{y} / B_{x}}$ $=0.14039$ とする。平行四辺形板としては, $21.8 \times 8.0$ 
のものを考え, $6 \times 6$ の skew network を組んだので, $K=\lambda_{y} / \lambda_{x}=8.0 / 21.8=0.36697$ となる。したがって, 計 算に必要な数值は, 文献 4) にしたがい, $A=K^{2} / \alpha=$ $0.95923, B=K \cdot \tan \varphi\left(\varphi=60^{\circ}\right)=0.63562$ である。縁辺 を自由辺としたので, $J=0$ である。載荷計算の研究に 用いた $\kappa=0.26$ を用いて, 計算を, 中心に関して対称 な 1 次振動, 中心に関して逆対称な 1 次振動に限って求 めることとしよう。前者では 18 元の matrix equation の, 後者では 17 元の matrix equation の第 1 次固有值 を求めることに帰する。NEAC 2203 による計算結果 は，1次振動に対して，つぎのとおりである。

$$
\begin{aligned}
k=\rho p^{2} \lambda_{y}{ }^{4} / B_{y} & =0.08849 \quad \text { 対称 } 1 \text { 次振動に対して } \\
& =0.15033 \text { 逆対称 } \quad "
\end{aligned}
$$

さて $, \rho=\left(628 / 10^{4}\right) / 9.8 \times 10^{2}, \quad \lambda_{y}=800 / 6, \quad B_{y}=166 \times$ $2.1 \times 10^{6}$ とすれば, 対称 1 次振動に対して, $f=6.4$ cycle/sec, また, 逆対称 1 次振動に対して, $f=8.1$ cycle / sec となる。

この場合のモードを示せば，図一3のようである。

図一3振動モード（板理論による）( $(\kappa=0.26)$

(a) 中心に関して対称な 1 次振動

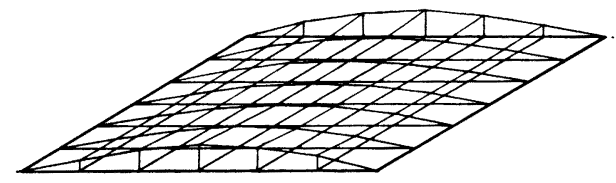

（b）中心に関して逆対称な 1 次振動

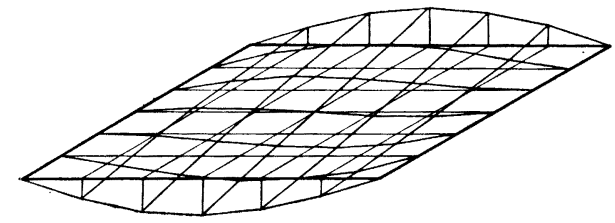

\section{（4）格子桁理論による検討}

純信橋注そもも直格子桁構造である。上において は,これを板構造に変換 して解いたものである。 これを格子桁構造そのも のとして, 解くことにし た。用いたプログラムは 三菱重工業(株)の藤野勉 博士の開発した“分布質 量平面構造系の面外固有 振動計算法”,であり，使 用した計算機は IBM 7044 である。格子桁構 造の格点が比較的少ない ので，格点間の中央にさ らに一つの点をとって精 度をあげることとした。 用いた数值は, 断面 2 次
モーメントが, 外桁, 内桁に対しては前述のとおり, 横 桁に対して $86600 \mathrm{~cm}^{4}$, 対傾構に対して $33400 \mathrm{~cm}^{4}$, $w=628 \mathrm{~kg} / \mathrm{m}^{2}$ である。

この場合の計算結果を, 表一2 に示す。

表一2 格子桁理論による純信橋の固有振動数 (cycle/sec)

\begin{tabular}{c|c|cc}
\hline Mode & 固有振動数 & \multicolumn{1}{c}{ 備 } & \multicolumn{1}{c}{ 考 } \\
\hline 1 & 6.5592 & 中心に関して対称 1 次 \\
2 & 9.1339 & " & 逆対称 1 次 \\
3 & 17.4439 & " & 対称 2 次 \\
4 & 24.4993 & " & 逆対称 2 次 \\
5 & 31.1781 & " & 対称 3 次 \\
6 & 31.5562 & " & 逆対称 3 次 \\
\hline
\end{tabular}

この場合の振動モードを示せば 図一4 のようである。

\section{(5) 総括, 検討}

以上, 各種の方法によって, 純信橋の 1 次の固有振動 数 (cycle/sec) を求めたが，これをまとめると，つぎの ようである。

a) 桁理論 : 5.5

b）直交異方性長方形板理論 : 斜角を無視する。 橋軸に対称振動 $6.1(\kappa=0), 6.4(\kappa=0.26)$ ， $6.6(\kappa=1)$

橋軸に逆対称振動 $7.5(\kappa=0), 7.7(\kappa=0.26)$ $7.8(\kappa=1)$

c) 直交異方性平行四辺形板理論 : 斜角を考慮す る。
中心に関して対称振動
$6.4(\kappa=0.26)$
中心に関して逆対称振動
$8.1(\kappa=0.26)$

d) 格子桁理論 :

中心に関して振動対称 $\quad 6.5(\kappa=0$ にあた る)

中心に関して逆対称振動 $9.1(\kappa=0$ にあた る)

斜角を無視した直角異方性板長方形板理論は参考のた
図一4振動モード（格子桁理論による）

（a）中心に関して対称な 1 次振動

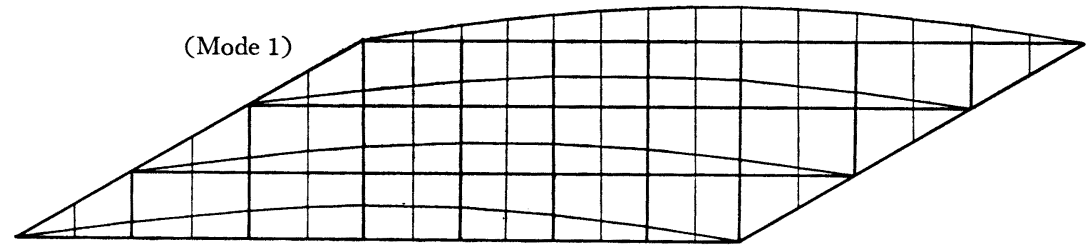

（b）中心に関して逆対称な 1 次振動

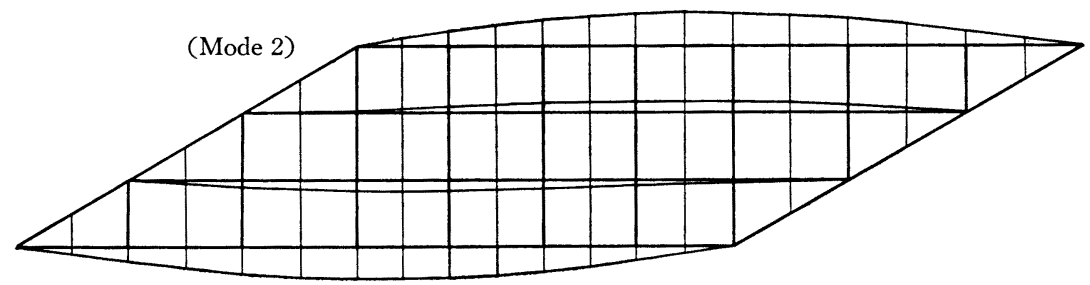


めに計算したものであるから，これを除外して，自動車 荷重走行によって得られた $f=8.5$ を，a)，c), d) の值 と比較してみよう。 $f=8.5$ がいかなるモードに対応す るものか不明のまま残してきたが，中心に関して逆対称 の 1 次振動に対応するものであると推察される。実測值 の $f=8.5$ を桁理論によって論じていけないこ とはよくわかる。斜角を考慮して，c)あるいは d)のような，実際に忠実な計算法をとれば， およそ，実測值が説明できるものと思う。

なお, 純信橋の固有振動数を求めるにあたっ ては, 自動車荷重走行によった。もし, 中央点 付近を Oscillator で加振したならば，中心に関 して対称な 1 次振動が出たはずである。実験の 失敗である。

\section{第 2 編 新歌島橋模型の固有振 動数についての研究}

\section{1. 概 説}

新歌島橋については第 3 編に述べるが，本橋 の設計にあたって，図一5 のようなアクリライ 卜模型がつくられ，載荷実験が行なわれた。こ の模型 (直桁橋, 斜桁橋) を用いて, 固有振動 数の測定が行なわれた。この結果を利用して, 直交異方性平行四辺形板理論による計算値を実測值と比。 較して，計算法の有效性を検討したいと思う。

\section{図一5 新歌島橋の模型}
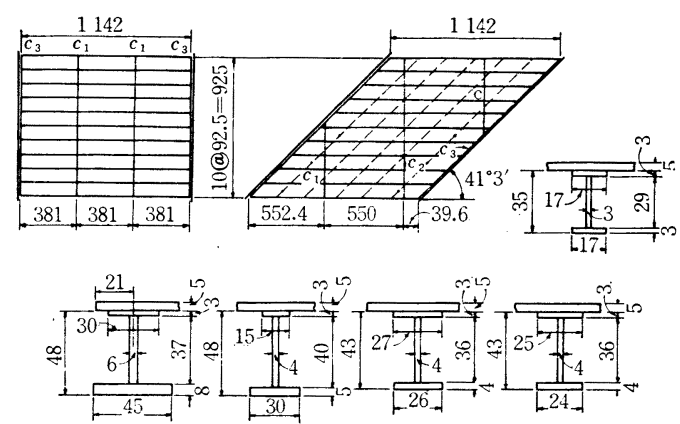

模型の詳細は文献 5) に述べられているが，改めて示 すと，つぎのとおりである。

本橋の模型析橋の諸元はつぎのようである。

外桁: $E=2.9 \times 10^{4} \mathrm{~kg} / \mathrm{cm}^{2}, \quad r=1380 \mathrm{~kg} / \mathrm{m}^{3}, A=$ $10.0825 \mathrm{~cm}^{2}, \quad l=114.2 \mathrm{~cm}, \quad I=43.48 \mathrm{~cm}^{4}$

内桁 : $E=2.9 \times 10^{4} \mathrm{~kg} / \mathrm{cm}^{2}, \quad r=1380 \mathrm{~kg} / \mathrm{m}^{3}, \quad A=$

$8.175 \mathrm{~cm}^{2}, l=114.2 \mathrm{~cm}, I=31.16 \mathrm{~cm}^{4}$

この直（斜）桁橋の固有振動数を桁理論によって計算 すれば，外桁に対して $f=35.9 \mathrm{cycle} / \mathrm{sec}$, 中桁に対し て, $f=33.7 \mathrm{cycle} / \mathrm{sec}$ となる。

\section{図-6 Block Diagram}

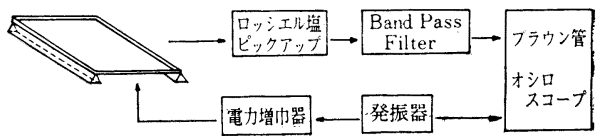

図-7

（b）斜桁橋模型の実測値之計算值と の比較

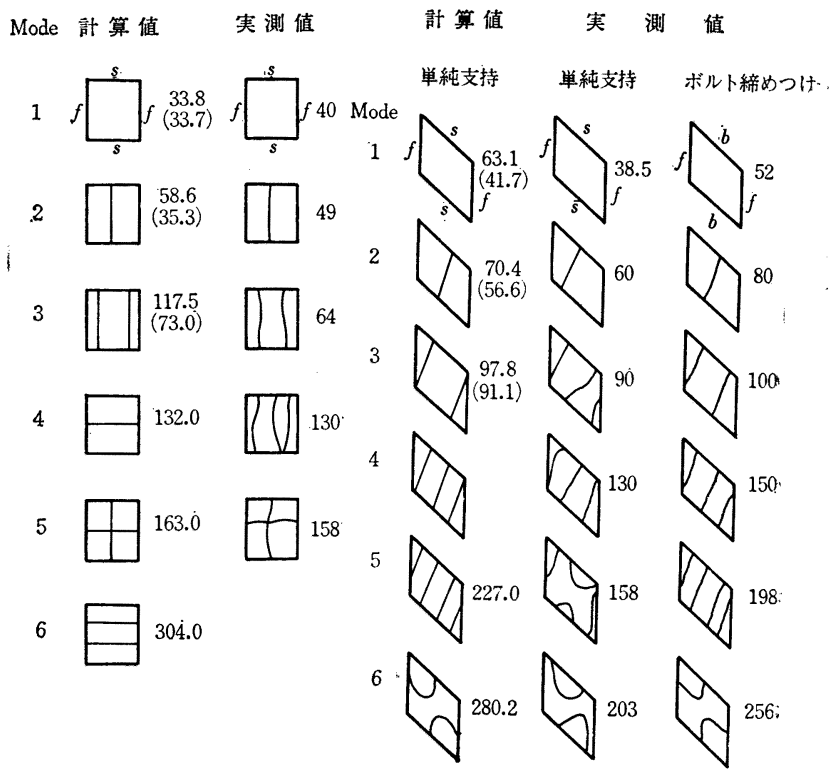

実験にあたっては，直桁橋，および，斜析橋の模型の 桁の両端を knife edge で単純支持としてささえた。固 有振動数測定のための Block Diagram は, 図一6 のと おりである。治具上に設置された模型をロッシェル塩ピ ックアップで摺動捜查し，この振動をブラウン管オシロ: スコープの $\mathrm{Y}$ 軸に入れ，一方，加振周波数を同じく $\mathrm{X}$ 軸に入れ，リサージュ図形を描かせることにより，固有 振動数, および, 振動モードを求めた。

また，この模型は製作上の誤差が大きく(これは不可 避である), また，支持方法も困難であるため，振動の 際の支持部におけるガタは不可避である。これによるリ サージュ図形のくずれを逃げるため，Band Pass Filter を用いた。

斜桁橋については，ガタを除去するために，支持端に そって, ボルト 12 本で締めつけた状態でも実験を行な った。

実験結果を図一7 (a), (b) に示す。 $s$ は単純支持, $f$ は自由, $b$ はボルト締付けを示す。

\section{2. 実測值と計算値との比較}

以上のようにして得た実測值を計算値と比較しょう。 計算值としては, 主として, 直交異方性板理論によるも のを求め，直析橋に対しては，長方形板理論を，斜析橋: 
に対しては平行四辺形板理論を用いた。なお，あわせて 格子桁理論を用いた。

\section{（1）直交異方性板理論による検討}

\section{a) 長方形板理論}

直桁橋の場合 $B_{x}=31.16 E / 9.25=3.369 E, B_{y}=$ $0.339 E$ (これらは文献 5) による) の, $l=114.2 \mathrm{~cm}$ の 直交異方性板が, $2 b=92.5 \mathrm{~cm}$ の両縁で, $E J_{R}=43.48$ $E$ の弾性ばりに支持されているものとして計算を進め る。この場合, 計算に必要な数值は, つぎのようであ る。以下す心゙て, $n=1$ の場合のみを考える。

$\alpha=0.04884, \phi=0.4044, \rho=1.4469 \times 10^{-6}$,

$\left(\rho p^{2} / B_{x}\right)(l / \pi)^{4}=0.252 p^{2} \times 10^{-4}$

$\kappa=0$ と $\kappa=1$ の 2 つ場合に対して固有振動数 $f$ (cycle /sec）を計算すると，つぎのようになる。

\begin{tabular}{l|c|c|c}
\hline & 対 称 1 次 & 逆対称 1 次 & 対 称 2 次 \\
\hline$\kappa=0$ & 34.0 & 39.4 & 55.7 \\
$\kappa=1$ & 38.9 & 43.5 & 65.0 \\
\hline
\end{tabular}

これより, $\kappa=0.5$ の場合を $f_{\kappa}=f_{0}+\left(f_{1}-f_{0}\right) \sqrt{\kappa}$ によって推察すると，

対称 1 次に対して $f=37.5$

逆対称 1 次に対して $f=42.3$

対称 2 次に対して $f=62.2$

となる。実験值は，40,49, 64 となっているから，比較 的よく一致しているといえよう。

b) 直交異方性平行四辺形板理論 この斜桁橋の模 型を直交異方性平行四辺形板とみなす。直桁橋の場合に は，直交異方性長方形板が弾性ばり支持されると考えた が，斜桁橋の場合には，さきの純信橋の場合と同様に縁 辺自由とみなす。用いた skew network を図一8に示 す。

\section{図一8 固有値計算の対象とした skew network}

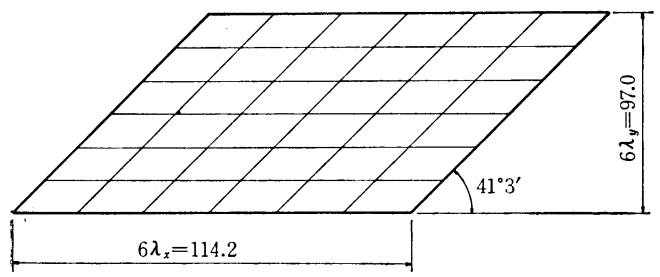

$\Sigma I=31.16 \times 9+43.48 \times 2=367.44$ であるから,$B_{x}$ $=367.44 E / 97=3.7880 E$ とする。 $B_{y}=0.339 E$ はも とのままである。したがって， $\alpha=\sqrt{B_{y} / B_{x}}=0.29915$ となる。 skew network で板をおおい, 縦横 6 等分する ものとすると, $K=97.0 / 114.2=0.84939$ となる。したが って, 固有值計算に必要な数值は, つぎのようである。

$A=K^{2} / \alpha=2.41171$

$B=K \cdot \tan \varphi=0.97539\left(\varphi=48^{\circ} 57^{\prime}\right)$

$\kappa=0,0.5,1.0$ (仮定)
NEAC-2203 による固有値 $\rho p^{2} \lambda_{y}{ }^{4} / B_{y}$ の計算值は, つぎのようである。

\begin{tabular}{c|c|c|c}
\hline$\kappa$ & 0 & 0.5 & 1.0 \\
\hline 中心に関し対称 1 次 & 0.43300 & 0.61343 & 0.77927 \\
中心に関し逆対称 1 次 & 0.53814 & 0.84289 & 1.08867 \\
中心に関し対称 2 次 & 1.10975 & 1.71717 & 2.20991 \\
中心に関し逆対称 2 次 & 2.67296 & 3.67637 & 4.60563 \\
\hline
\end{tabular}

さて $, \rho=1.4469 \times 10^{-6}, \lambda_{y}=97 / 6, \quad B_{y}=0.339 \cdot 2.9 \times$ $10^{4}$ とすれば， $f=p / 2 \pi$ (cycle/sec) の值はつぎのよう である。

\begin{tabular}{c|c|c|c}
\hline \multicolumn{1}{c|}{$\kappa$} & 0 & 0.5 & 1.0 \\
\hline 中心に関し対称1 次 & 33.0 & 39.4 & 42.5 \\
中心に関し逆対称 1 次 & 36.8 & 46.2 & 52.4 \\
中心に関し対称 2 次 & 53.0 & 65.8 & 74.6 \\
中心に関し逆対称 2 次 & 82.2 & 96.3 & 108 \\
\hline
\end{tabular}

この場合の 1,2 次振動のモードのみを，図一9, 10 に示す。

図一9 斜桁橋の振動モード（板理論による）（ $(\kappa=0.5 ）$ 模型 1 次
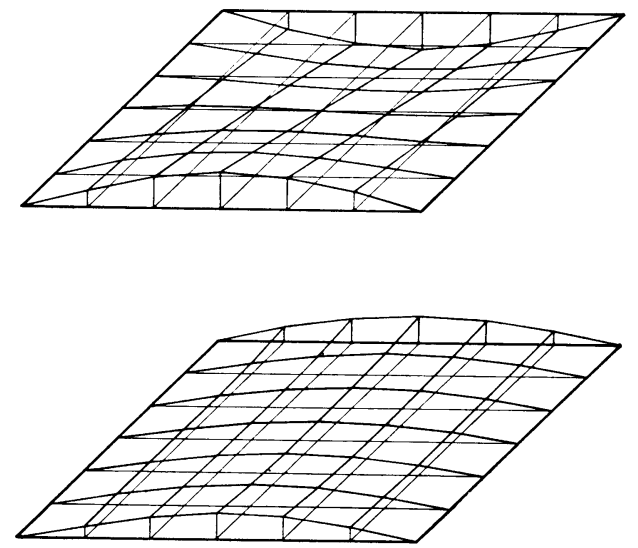

図一10 斜桁橋の 2 次振動のモード(板理論による) $(\kappa=0.5)$ 模型 2 次
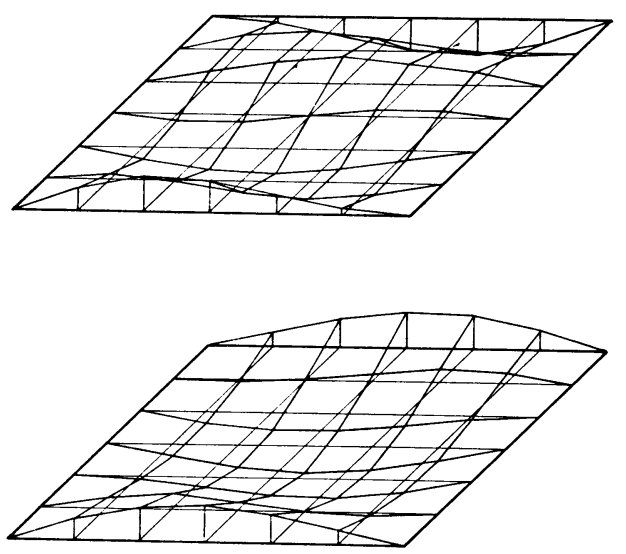
(a)

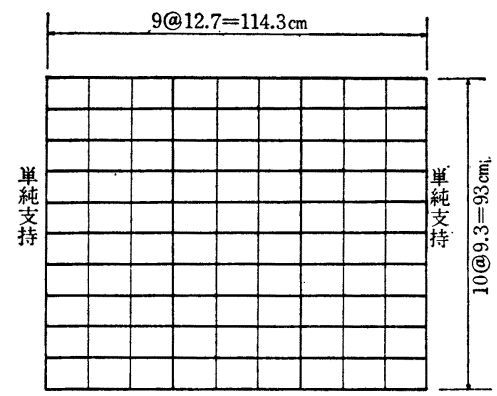

\section{(2) 格子桁理論}

以上は直格子斜桁橋を直交異方性板理論によって解い たが，格子桁構造そのものとして，純信橋の場合と同様 に，さきに示したプログラムによって，IBM 7044 によ って解いた。その結果を，図一7 に示す。（）を付け たのは, ねじり剛性を無視した場合の值を示す。

この場合の計算においては, 直格子斜桁橋をそのまま 取り扱うと非常に繁雑になるので, 図一11 のように, 計算しやすい形状におきかえて, 計算を進めた。計算に 用いた数值は省略する。くわしくは, 文献 6) を参照さ れたい。

(3) 総 括

以上述べたところをまとめると, つぎの 表一 3,4 の ようになる。

表-3 直桁檽模型の固有振動数の実験値と計算値との比較 (単位 : cycle/sec)

\begin{tabular}{|c|c|c|c|c|c|c|c|}
\hline q & - & 1 & 2 & 3 & 4 & 5 & 6 \\
\hline \multicolumn{2}{|c|}{$\begin{array}{l}\text { 橋軸中心線に } \\
\text { 関し }\end{array}$} & $\begin{array}{l}\text { 対 称 } \\
(1 \text { 次 }\end{array}$ & $\begin{array}{l}\text { 逆対称 } \\
\text { (1次) }\end{array}$ & $\begin{array}{l}\text { 対 称 } \\
(2 \text { 次) }\end{array}$ & & & \\
\hline 実 & 験 & 40 & 49 & 64 & 130 & 158 & \\
\hline 計 & 格子析理論 & $\begin{array}{c}(33.7) \\
33.8\end{array}$ & $\begin{array}{c}(35.3) \\
58.6\end{array}$ & $\begin{array}{l}(73.0) \\
117.5\end{array}$ & 132 & 163 & 304 \\
\hline 算 & 直交異方性 & 34.0 & 39.4 & 55.7 & & & \\
\hline \multirow{2}{*}{ 值 } & & 37.5 & 42.3 & 62.2 & & & \\
\hline & 長方形板理論 & 38.9 & 43.5 & 65.0 & & & \\
\hline
\end{tabular}

注：格子析理論の欄で（）をつけたのは, ねしり用性を無視した場 合を示す。直交異方性長方形板理論の欄は上より $\kappa=0,0.5,1.0$ に対する值を示す。

\section{表-4 斜桁橋模型の固有振動数の実験值と計算值との比較} (単位: cycle/sec)

\begin{tabular}{|c|c|c|c|c|c|c|c|}
\hline E & - & 1 & 2 & 3 & 4 & 5 & 6 \\
\hline \multicolumn{2}{|c|}{$\begin{array}{l}\text { 橋軸中点に関 } \\
\longleftarrow \tau\end{array}$} & $\begin{array}{l}\text { 対 称 } \\
\text { (1次) }\end{array}$ & $\begin{array}{l}\text { 逆対称 } \\
(1 \text { 次 })\end{array}$ & $\begin{array}{l}\text { 対 称 } \\
(2 \text { 次 })\end{array}$ & $\begin{array}{l}\text { 逆対称 } \\
(2 \text { 次 })\end{array}$ & $\begin{array}{l}\text { 詨 称 } \\
(3 \text { 次 })\end{array}$ & $\begin{array}{l}\text { 逆対称 } \\
\text { (3 次) }\end{array}$ \\
\hline \multirow{2}{*}{ 蹇 } & \multirow{2}{*}{$\begin{array}{l}\text { 単純支持 } \\
\text { ボルト卜 } \\
\text { 揥めつけ }\end{array}$} & 38.5 & 60 & 90 & 130 & 158 & 203 \\
\hline & & 52 & 80 & 100 & 150 & 198 & 256 \\
\hline 計 & 格子桁理論 & $\begin{array}{l}(41.7) \\
63.1\end{array}$ & $\begin{array}{c}(56.6) \\
70.4\end{array}$ & $\begin{array}{l}(91.1) \\
97.8\end{array}$ & & 227 & 280.2 \\
\hline \multirow[t]{2}{*}{ 算 } & \multirow{2}{*}{ 直交異方性 } & 33.0 & 36.8 & 53.0 & 82.2 & & \\
\hline & & 39.4 & 46.2 & 65.8 & 96.3 & & \\
\hline 值 & 板 理 論 & 42.5 & 52.4 & 74.6 & 108 & & \\
\hline
\end{tabular}

注 : 計算値の欄の説明は表-3 の注て同一で志る。
図-11

(b)

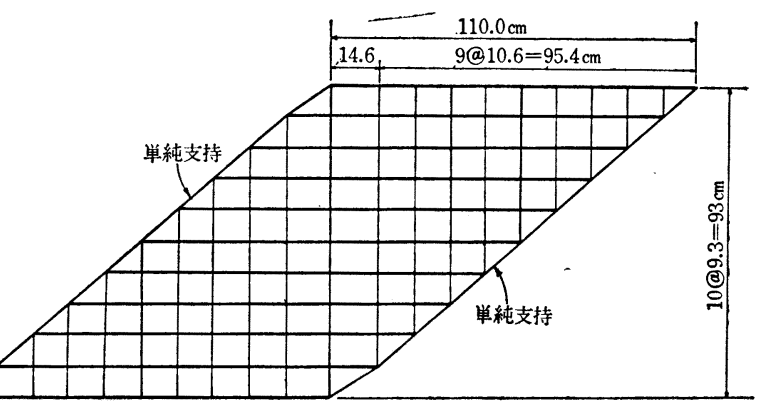

まず，直桁橋について考えよう。もし， aspect ratio， および，斜角を無視すれば， 1 次振動に対して，平均 $34.8 \mathrm{cycle} / \mathrm{sec}$ となる。

mode 1 の振動に対しては, 実測値は格子桁理論, お よび板理論による計算值と比較的よく一致しているし, またこれは桁理論によるものとよく一致しているが，こ れは当然である。

問題は mode 2 以下である。直桁橋において, $f=49$ cycle/sec に対し, 板理論では, $39.4(\kappa=0), 42.3(\kappa=$ 0.5), 43.5( $(\pi=1.0) \mathrm{cycle} / \mathrm{sec}$ である。文献 5) からわ かるとおり，たわみの測定からすると， $0.5<\kappa<1.0$ で あろう。このように考えると, mode 2 においては, (実測値)/(計算值) の值が $1.16 〜 1.12$ の間にあること になり，常識的に納得しえよう。

mode 3 については, 実測值の 64 , 格子桁理論によ る $117.5 \mathrm{cycle} / \mathrm{sec}$ に疑問があると思われるので, これ 以上, 追究することをやめよう。

斜桁橋の場合について検討しよう。各 modeにおける $f(\kappa=1) / f(\kappa=0)$ の值は $1.3 \sim 1.4$ であって, おおむね, 一致している。 mode 1 の固有振動数については, おお むね, 納得できよう。 mode 2,3 についても, (実測值)/ (計算值) は, 板理論によれば, 妥当といえるであろう。

\section{第 3 編＼cjkstart新歌島橋（実橋）の固有振 動数についての研究}

\section{1. 固有振動数の測定}

新歌島橋は橋格一等橋, スパン $22.84 \mathrm{~m}, 2$ 連, 橋長 $47.40 \mathrm{~m}$, 全幅員 $20.70 \mathrm{~m}$ (車道 $16.0 \mathrm{~m}$, 歩道 $2 @ 2.0$ m) の単純支持合成桁橋である。斜角は $48^{\circ} 57^{\prime}$, 荷重分 布用横桁 3 本をもつ。その平面骨格図を $1 / 20$ 縮尺にし たものが, 図一5 に示されている。

本橋の振動数の測定は昭和 41 年 2 月に行なわれた。 測定箇所は 図一12 のとおりである。数字は測定点の番 号であり, $2^{\prime}, 5^{\prime}$ は 1〜6 の測定を完了したあと, pick up 2,5 を $2^{\prime}, 5^{\prime}$ の位置に設置して 測定したものであ 
図-12 新歌岛橋の測定点

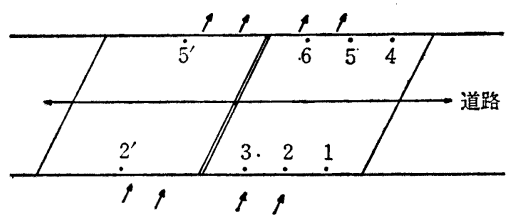

る。 pick up には N.D. 式変位計を用いた。これは可 動コイル型の over damping の速度計で, $0.3 \sim 30 \mathrm{c} / \mathrm{s}$ で flat な周波数特性をもつものである。N.D. 式変位計 6 台で pick up された振動は増幅器をへてビジグラフ で記録した。

測定は車が通過したあとの自由振動と, 車が全く通過 しない場合の常微振動を記録して行なったが, 前者では よい結果が得られなかった。

\section{2. 測定結果および検討}

測定の結果得られた記録波形の実例を示すと, 非常に 複雑となるので省略する。測点 $2^{\prime}$ の常微振動の波形に ついてパワースペクトルを求めると, 図一13 のように なる。これによれば, 固有振動数は $5.7 \mathrm{cycle} / \mathrm{sec}$ 対数 減衰率は 0.662 となる。

振動モードは対

称的ではない。特 に下流側において 変則的であり，模 型実験における第 1 モードと第 2 モ ードが混合したよ らな形式となって いる。これを, 図 -14 に示す。

さて, 本橋の固 有振動数を検討し てみよう。

\section{(1) 桁理論}

本橋の 11 本の 主桁の断面 2 次モ ーメントの総和は $I=14603000 \mathrm{~cm}^{4}$,

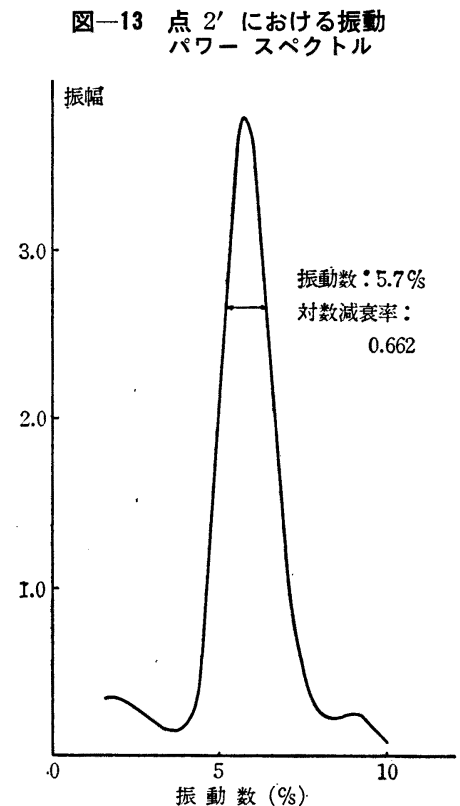

図一14振钦モード（実測による）

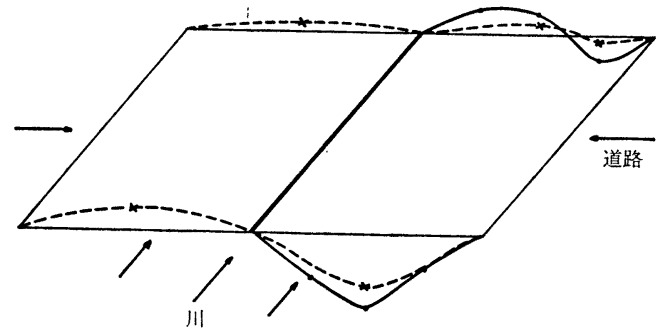

図一15 振動モ一ト $(\kappa=0.2)$
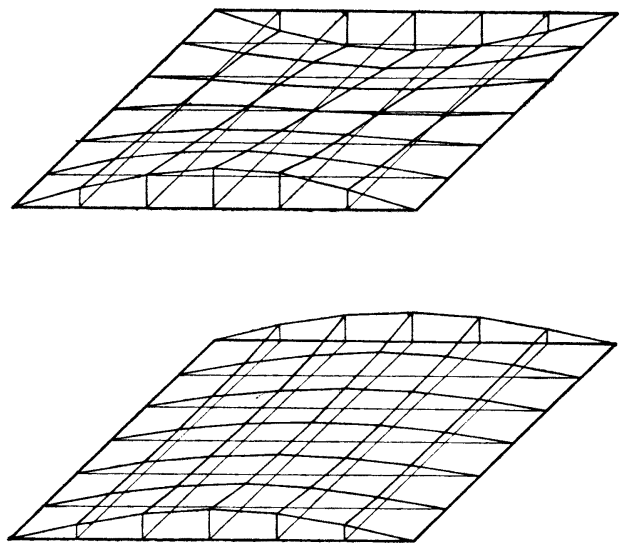

単位長さあたりの主桁の重量の総和は $A r=15604 \mathrm{~kg} / \mathrm{m}$ $=156.04 \mathrm{~kg} / \mathrm{cm}$ である。

$$
f=\left(\pi / 2 l^{2}\right) \sqrt{E I g / A r}
$$

において $l=22.84 \mathrm{~m}=2284 \mathrm{~cm}, E=2.1 \times 10^{6} \mathrm{~kg} / \mathrm{cm}^{2}$, $I=14.603 \times 10^{6} \mathrm{~cm}^{4}, g=980 \mathrm{~cm} / \mathrm{sec}^{2}, A r=156.04 \mathrm{~kg} / \mathrm{cm}$ を代入すれば,

$$
f=4.16 \div 4.2 \mathrm{cycle} / \mathrm{sec}
$$

となって，測定值を説明しえない。

\section{(2) 直交異方性平行四辺形板理論}

この橋を Guyon-Massonnet 流に $2284 \times 2070 \mathrm{~cm}$ の 縁辺自由の直交異方性平行四辺形板とみなす。 $B_{x}=$ $14.603 \times 10^{6} E_{s} / 2070=7055 E_{s}$ とする。 $B_{y}$ としては， 横桁の断面 2 次モーメントの和 $2.41 \times 10^{6} \mathrm{~cm}^{4}$ と床板厚 さ $18 \mathrm{~cm}$ のみを考えて,$B_{y}=\left(2.41 \times 10^{6} E_{s} / 2284\right)+$ $\left(18^{3} / 12\right)\left(0.1 E_{s}\right)=1103 E_{s}$ とする。したがって， $\alpha=$ $\sqrt{B_{y} / B_{x}}=\sqrt{1103 / 7055}=0.3954$ となる。縦横 6 等分 の skew network を組むことにすれば， $K=2$ 070/2 284 $=0.9063$ となる。したがって, 固有值計算に必要な数 值はつぎのようである。

$$
\begin{aligned}
& A=K^{2} / \alpha=2.0773 \\
& B=K \tan \varphi=1.04075\left(\varphi=48^{\circ} 57^{\prime}\right) \\
& J=0 \\
& \kappa=0,0.2,0.5,1.0 \text { (仮定) }
\end{aligned}
$$

$\kappa$ の值は計算で求めず, 仮定した。

NEAC-2203 による固有值 $\rho p^{2} \lambda_{y}{ }^{4} / B_{y}$ の計算結果は つぎのようである。

\begin{tabular}{l|c|c|c|c}
\hline \multicolumn{1}{c|}{$\kappa$} & 0 & 0.2 & 0.5 & 1.0 \\
\hline 中心に関し対称 1 次 & 0.32847 & 0.40452 & 0.50985 & 0.67536 \\
中心に関し逆対称 1 次 & 0.42876 & 0.54842 & 0.70111 & 0.92404 \\
中心に関し対称 2 次 & 0.99946 & 1.20939 & 1.48258 & 1.88731 \\
中心に関し逆対称 2 次 & 2.46460 & 2.79275 & 3.26724 & 4.03952 \\
\hline
\end{tabular}

さて $, \rho=156.04 / 2070 \cdot 980=75.4 \times 10^{-6}, \quad \lambda_{y}=2070 / 6$ $=345, B_{y}=1103 E_{s}=2.316 \times 10^{6}$ とすれば, $f=p / 2 \pi$ (cycle/sec) の值は, つぎのようである。 


\begin{tabular}{c|r|r|r|r}
\hline$\kappa$ & 0 & 0.2 & 0.5 & 1.0 \\
\hline 中心に関し 対称 1 次 & 4.2 & 4.7 & 5.2 & 6.0 \\
" 逆対称 1 次 & 4.8 & 5.4 & 6.1 & 7.0 \\
" 対称 2 次 & 7.4 & 8.2 & 9.0 & 10.2 \\
" 逆対称 2 次 & 11.6 & 12.4 & 13.4 & 14.9 \\
\hline
\end{tabular}

$\kappa=0.2$ の場合の振動 モードを 1 次の場合について示 せば，図一15 のとおりである。

本橋の模型では $\kappa=0.5$ あたりであろうと推定した が, 実橋では $\kappa=0.2$ 程度であろうと思われる。したが って, 対称 1 次では, 縦横 6 等分の skew network に よっては $f \div 4.7 \mathrm{cycle} / \mathrm{sec}$ となる。この skew network は最も粗いものであるから，正しい值は 5 10\%ぐらい 大きいものと思われる。したがって, 対称 1 次振動に対

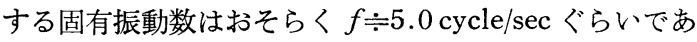
ろうと思われる。

さて, 実橋の測定值と計算値は一致せず, 一般に, そ の比は 10〜20\% 大きい。これは，多くの実験からも明 らかにされている。これらをあわせ考えると，本橋の測 定值 $f=5.7 \mathrm{cycle} / \mathrm{sec}$ は, ほぼ妥当なものと思われる。

これは，桁理論による $4.2 \mathrm{cycle} / \mathrm{sec}$ からはとうてい 説明し得ない。

\section{むすび}

以上において, 直格子斜桁橋——純信橋 $\left(60^{\circ}\right)$, 新歌 島橋 $\left(48^{\circ} 57^{\prime}\right)$ 一一対象として, その固有振動数を実験 的に求め, これを主として, 直交異方性平行四辺形板理 論による計算值と比較した。

最近, Guyon-Massonnet の方法で設計される直格子 直桁橋が比較的多いので，これと全く同一の stiffness ratio および, torsional parameter をもつ直格子斜桁 橋において, 斜角が $30^{\circ}, 45^{\circ}, 60^{\circ}$ のように変わると, 固有振動数がどのように変化するかを求めて, 図表にし たいと考えている。

純信橋の測定には, 三菱重工業 $\mathrm{K} K$ 広島造船所是松技
師，格子桁理論による計算には同社技術管理部大坂技 師，模型実験，および，新歌島橋の測定には同社神戸研 究所森田技師にお世話になった。ここに記して，謝意を 表する次第である。

直交異方性平行四辺形板理論による固有值の計算プロ グラムにおいて, 名古屋大学電子計算機 NEAC-2203の 記憶容量の関係上, skew network は $6 \times 6$ とせざるを 得ず，固有值の精度が多少悪いうらみはあるが，直交異 方性平行四辺形板理論と上記のプログラムとによる計算 值はおおむね実測值を説明しえているであろう。

\section{参考文 献}

1）成岡 ・平井：合成格子桁橋の 自由振動周期について, 土 木学会論文集, 35 (31.6), pp. 25 30.

Masao Naruoka and Hiroshi Yonezawa : A Study of the Period of the Free Lateral Vibration of the Beam Bridges by the Theory of Orthotropic Rectangular Plates, Ingenieur Archiv, 26 (1958), S. 20-29.

2）成岡・大村・川野・古賀 : 純信橋（合成・直格子・斜桁 橋）の研究一直交異方性 平行四辺形板の 理論の応用一 一, 土木学会誌, 46.11 (昭.36.11), pp. 27 31.

3) Masao Naruoka und Hiroshi Ohmura: Berechnung und Belastungsversuche einer schiefwinklig gelagerten orthogonalen Trägerrostbrücke, Stahlbau, 31 (1962), S. 340-344.

4) Masao Naruoka and Hiroshi Ohmura : On the Ana lysis of a Skew Girder Bridges by the Theory of Orthotropic Parallelogram Plates, Publications of IABSE, 19 (1959), pp. 231-256.

Masao Naruoka und Hiroshi Ohmura : Über die Berechnung der Einflusskoeffizienten tür Durchbiegung und Biegemoment der orthotropen Parallelo gram-Platte, Stahlbau, 28 (1959), S. 187-194.

5) Masao Naruoka, Hiroshi Ohmura and Tomohiro Yamamoto: On the Model Tests of Skew Girder Bridges, Publications of International Association for Bridge and Structural Engineering, 21 (1961), pp. 193-215, Zürich.

6) 三菱重工業株式会社神戸研究所 : 斜桁 橋 - 直桁橋模型振 動実験, 資料番号, 25033012 , 昭和 41 年 4 月

(1966.9.28 - 受付) 